\title{
Bibliography
}

\section{Books and articles}

Adler, E. and Barnett, M.N. (1998) 'A framework for the study of security communities', in E. Adler and M. Barnett (eds), Security Communities (Cambridge: Cambridge University Press).

Albrecht, U. et al. (2004) 'A Human Security Doctrine for Europe: The Barcelona Report of the Study Group on Europe's Security Capabilities', Barcelona, 15 September 2004, available at www.cercle.lu/article.php3?id_article =588 (accessed 13 September 2005).

Alecu de Flers, N. and Regelsberger, E. (2005) 'The EU and inter-regional cooperation', in C. Hill and M. Smith (eds), International Relations and the European Union (Oxford: Oxford University Press).

Aliboni, R. (2004) 'Common languages on democracy in the Euro-Mediterranean Partnership', EuroMeSCo Paper, 31.

Babarinde, O. and Faber, G. (2004) 'From Lomé to Cotonou: Business as usual?', European Foreign Affairs Review, 9:1.

Baldwin, D. (1997) 'The concept of security', Review of International Studies, $32: 1$.

Barnett, M. and Duvall, R. (eds) (2005) Power in Global Governance (Cambridge: Cambridge University Press).

Baumann, R., Rittberger, V. and Wagner, W. (2001) 'Neorealist foreign policy theory', in V. Rittberger (ed.), German Foreign Policy since Unification: Theories and Case Studies (Manchester: Manchester University Press).

Béchat, J.-P. and Rohatyn, F. G. (eds) (2003) The Future of the Transatlantic Defense Community (Washington, DC: CSIS).

Bertram, C., Boyer, Y., Heisbourg, F. and Schild, J. (2002) Starting Over: For a Franco-German Initiative in European Defence (Berlin: Stiftung Wissenschaft und Politik).

Bianchini, S., Marko, J., Craig, R., Privitera, F. and Uvalie, M. (2006) 'Concluding remarks of the Forli International Conference', Forli, 20-21 January 2006.

Bildt, C. (2005) 'Europe Must Keep Its Soft Power', Financial Times, 1 June 2005, available at www.christusrex.org/www1/news/ft-6-1-05b.html (accessed 12 August 2006). 
Biscop, S. (2005) The European Security Strategy: A Global Agenda for Positive Power (Aldershot: Ashgate).

Biscop, S. (2004) 'The European Security Strategy: Implementing a distinctive approach to security', Sécurité \& Stratégie, paper 82.

Boin, A. and Rhinard, M. (eds) (2005) 'Shocks without frontiers: Transnational breakdowns and critical accidents', EPC Issue Paper, 42.

Boulding, K. (1962) Conflict and Defence (New York: Harper and Row).

Brenner, M. (2002) 'Europe's new security vocation', McNair Paper, 66 (Washington, DC: Institute for National Strategic Studies and National Defense University).

Bulletin Quotidien Europe (2005a) 'European Parliament resolution on the annual report from the Council of to the European Parliament on the main aspects and basic choices of CFSP, including the financial implications for the general budget of the European Communities', Europe Documents, 22 April 2005.

Bulletin Quotidien Europe (2005b) '(EU)EU/Iran/Nuclear: Hassan Rowhani recommends EU-3 to not rule out the Iranian Proposal on limited uranium enrichment activities, in effort to keep negotiations on track', 21 April 2005.

Bulletin Quotidien Europe (2005c) ‘(EU)EU/Iran/Nuclear: Iranians believe new negotiations steering committee meeting should allow for progress', 29 April 2005.

Bulmer, S., Jeffery, C. and Paterson, W. E. (2000) Germany's European Diplomacy: Shaping the Regional Milieu (Manchester: Manchester University Press).

Bundeswehr (2004) 'Finanzplanung Einzelplan 14', available at www. bundeswehr.de/pic/forces/040623_500_finanzplan114.gif (accessed 17 November 2004).

Busek, E. (2004) 'Presentation at the Royal Institute of International Affairs, Delivered at Chatham House', London, 17 December, available at www. stabilitypact.org/pages/speeches/detail.asp? $y=2004 \& \mathrm{p}=16$ (accessed 12 August 2006).

Buzan, B., Wæver, O. and de Wilde, J. (1998) Security: A New Framework for Analysis (Boulder, CO: Lynne Rienner).

Cameron, F. and Rhein, E. (2005) 'Promoting political and economic reform in the Mediterranean and Middle East', EPC Issue Paper, 33.

Caporaso, J. (2000) 'Changes in the Westphalian order: Territory, public authority, and sovereignty', International Studies Review (Special Issue: Continuity and Change in the Westphalian Order), 2:2.

Caporaso, J. (1996) 'The European Union and forms of state: Westphalian, regulatory or post-modern?', Journal of Common Market Studies, 34:1.

Chauvet, L. and Collier, P. (2004) Development Effectiveness in Fragile States: Spillovers and Turnarounds (Oxford: Oxford University Centre for the Study of African Economies). 
Checkel, J. T. (1998) 'The constructivist turn in international relations theory', World Politics, 50:2.

Christensen, T. J. and Snyder, J. (1990) 'Chain gangs and passed bucks: Predicting alliance patterns in multipolarity', International Organization, 44:2.

Congressional Budget Office (2003) Congressional Budget FY 2003: National Nuclear Security (Washington, DC: GPO).

Cooper, R. (2003) The Breaking of Nations: Order and Chaos in the Twentyfirst Century (London: Atlantic Books).

Cottey, A. and Averre, D. (eds) (2002) New Security Challenges in Postcommunist Europe: Securing Europe's East (Manchester: Manchester University Press).

Cottey, A., Edwards, T. and Forster, A. (2002) 'Beyond Prague', NATO Review, 50:3.

Cronin, D. (2005) 'UN fears battle groups will cut numbers of EU peacekeepers', European Voice, 26 May-1 June: 6.

Dannreuther, R. (ed.) (2004) European Union Foreign and Security Policy: Towards a Neighbourhood Strategy (London: Taylor and Francis).

Den Boer, M. and Monar, J. (2002) 'Keynote article: 11 September and the challenge of global terrorism to the EU as a security actor', Journal of Common Market Studies, 40: annual review.

de Wijk, R. (2000) 'Convergence criteria: Measuring input or output', European Foreign Affairs Review, 5:3.

Dekker-Bellamy, J. S. (2004) 'Defining a European approach to preventing bioterrorism: Health security policy in the $21^{\text {st }}$ century', New Defence Agenda Background Report (Bioterrorism Reporting Group).

Economist, The (2006) 'Germany's armed forces: Abroad, by inches', 29 July 2006.

Edwards, G. (1997) 'The potential and limits of the CFSP: The Yugoslav example', in E. Regelsberger, P. de Schoutheete and W. Wessels (eds), Foreign Policy of the European Union (Boulder, CO: Lynne Rienner).

Egmont Group (2004) Statement of Purpose, Guernsey, 23 June 2004.

Egmont Group (2001) Principles for Information Exchange between Financial Intelligence Units for Money Laundering Cases, The Hague, 13 June 2001.

Eilstrup-Sangiovanni, E. and Verdier, D. (2005) 'European integration as a solution to war', European Journal of International Relations, 11:1.

Ekengren, M., Matzén, N. and Svantesson, M. (2006) The New Security Role of the European Union: Transnational Crisis Management and the Protection of Union Citizens (Stockholm: National Defence College).

Embassy of France in the United States (2005) 'Reform of French National Defense', at www.ambafrance-us.org/atoz/ref_def.asp (accessed 16 August 2006).

Embassy of France in the United States (2002) 'French Defense Overview', available at www.ambafrance-us.org/intheus/defense/defense.asp (accessed 16 August 2006). 
'EU-US Declaration on Combating Terrorism', Dromoland Castle, 26 June 2004. G8, 'G8 Counter-Terrorism Cooperation since September 11', available at http: //www.mofa.go.jp/policy/economy/summit/2002/coop_terro.html.

Everts, S (2004) 'The ultimate test case: Can Europe and America forge a joint strategy for the wider Middle East?', International Affairs, 80:4.

Falk, R. (2002) 'Revisiting Westphalia, discovering post-Westphalia', Journal of Ethics, 6:4.

Faria, F. (2004) 'Crisis management in sub-Saharan Africa: The role of the European Union', ISS-EU Occasional Paper, 51 (Paris: Institute for Security Studies).

Ferrero-Waldner, B. (2005) 'The role of crisis response in external relations: From needs to solutions: Enhancing civilian crisis response capacity of the European Union', speech/05/684, Brussels, 14 November 2005.

Financial Action Task Force on Money Laundering (2004) Annual Report, 2003-2004 (Paris: OECD).

Fuller, T. (2004) 'EU Looks on Warily as Its Eastern Neighbours Move In: Under One Flag', The International Herald Tribune, 29 April 2004 (accessed via Lexis-Nexis Executive).

G8 (2002) 'G8 Counter-terrorism Cooperation since September 11', available at www.mofa.go.jp/policy/economy/summit/2002/coop_terro.html (accessed 15 July 2005).

Gilpin, R. (1981) War and Change in World Politics (Princeton: Princeton University Press).

Goertz, G. (1994) Contexts of International Politics (Cambridge: Cambridge University Press).

Gomez, R. and G. Christou (2004) 'Economic foreign policy: The EU and the Mediterranean', in W. Carlsnaes, H. Sjursen, and B. White (eds), Contemporary European Foreign Policy (London: Sage).

Gonzales, K. W. (2004) 'Good fences make good neighbours: Ukrainian border security and western assistance', Problems of Post-Communism, 51:1.

Gouvras, G. (2002) 'Bioterrorism: Action by the European Community', European Health Forum Gastein, 25-28 September.

Graham, K. (2004) 'Towards effective multilateralism. The EU and the UN: Partners in crisis management', EPC Working Paper, 13.

Green, P. (1966) Deadly Logic: The Theory of Nuclear Deterrence (Columbus: Ohio State University Press).

Haine, J.-Y. (ed.) (2003) 'From Laeken to Copenhagen. European Defence: Core documents, vol. III', Chaillot Paper, 57 (Paris: Institute for Security Studies). Hall, R. and Fox, C. (2001/2002) 'Rethinking security', NATO Review, 49:4. Hampton, M. (1998/1999) 'NATO, Germany, and the United States: Creating positive identity in trans-Atlantia', Security Studies (special double issue), $8: 2 / 3$.

Hampton, M. and Sperling, J. (2002) 'Positive/negative identity: Europe’s future, Germany's past?’, Journal of European Integration, 24:4. 
Hänggi, H. and Tanner, F. (2005) 'Promoting security sector governance in the EU's neighborhood', EU-ISS Chaillot Paper, 80.

Hanrieder, W. F. (1989) Germany, Europe, America: The Foreign Policy of the Federal Republic of Germany, 1949-1989 (New Haven: Yale University Press).

Hanrieder, W. F. (1978) 'Dissolving international politics: Reflections on the nation-state', American Political Science Review, 72:4.

Harnisch, S. and Linden, R. (2005) 'German foreign policy', Dialogue, 6:17.

Hartley, K. (2006) 'Defence industrial policy in a military alliance', Journal of Peace Research, 43:4.

Heisbourg, F., Daguzan, J.-F., Lundmark, M. and Masson, H. (2003) 'The European industrial base and ESDP', in F. Heisbourg et al. (eds), Prospects on the European Defence Industry (Athens: Defence Analysis Institute).

Herz, J. H. (1957) 'The rise and demise of the territorial state', World Politics, 9:4.

Hill, C. (2001) 'The EU's Capacity for Conflict Prevention', European Foreign Affairs Review, 6:3.

Hill, C. (1994) 'The capabilities-expectations gap, or conceptualizing Europe's international role', in S. Bulmer and A. Scott (eds), Economic and Political Integration in Europe (Oxford: Blackwell).

Hill, C. (1993) 'The capability-expectations gap, or conceptualizing Europe's international role', Journal of Common Market Studies, 31:3.

Hill, C. and Smith, M. (2005) 'Acting for Europe? Reassessing international relations and the EU', in C. Hill and M. Smith (eds), International Relations and the European Union (Oxford: Oxford University Press).

Hoffmann, S. (1998) World Disorders: Troubled Peace in the Post-Cold War Era (Lanham, MD: Rowman \& Littlefield Publishers, Inc.).

Holsti, K. J. (1991) Peace and War: Armed Conflicts and International Order, 1648-1989 (Cambridge: Cambridge University Press).

Hombach, B. (1999) 'The Stability Pact: Breaking new ground in the Balkans', NATO Review, 47:4.

Hooghe, L. and Marks, G. (2003) 'Unraveling the central state, but how? Types of multi-level governance', American Political Science Review, 97:2.

Hopf, Ted (1998) 'The promise of constructivism in international relations theory', International Security, 23:1.

House of Lords/Select Committee on European Union (2005) 'Fourth Report: EU Battlegroups', 19 February 2005, available at www.publications. parliament.uk/pa/1d200506/1dselect/1deucom/16/16100.htm (accessed 19 July 2006).

Howorth, J. (2003) 'Why ESDP is necessary and beneficial for the Alliance', in J. Howorth and J. T. S. Keeler (eds), Defending Europe: The EU, NATO and the Quest for Autonomy (Basingstoke: Palgrave).

IAEA (2003) 'Nuclear security: Measures to protect against nuclear terrorism', GC(47)17, 20 August 2003. 
IAEA (2002) 'Nuclear security: Progress on measures to protect against nuclear terrorism', GOV/INF/2002/11-GC(46)/14, 12 August 2002.

IAEA (n.d.) 'IAEA Illicit Trafficking Database (ITDB)'.

Ideas Factory Europe (2004) 'European security: No strategy without politics', European Policy Centre Ideas Factory Report, 4.

IISS (2003) The Military Balance, 2003-2004 (Oxford: Oxford University Press).

Jepperson, R., Wendt, A. and Katzenstein, P. J. (1996) 'Norms, identity, culture and national security', in P. J. Katzenstein (ed.), The Culture of National Security: Norms and Identity in World Politics (New York: Columbia University Press).

Jervis, Robert (2002) 'Theories of war in an era of leading power peace', American Political Science Review, 96:1.

Jimeno-Bulnes, M. (2003) ' European judicial cooperation in criminal matters', European Law Journal, 9:5.

Judah, T. (2006) 'The EU must keep its promise to the Western Balkans', Centre for European Reform essays, July 2006.

Justice and Home Affairs Council (2006) 'First report on the Hague Programme'.

Kagan, R. (2003) Of Paradise and Power: America and Europe in the New World Order (New York: Knopf).

Keohane, R. (2001) 'Governance in a partially globalized world', American Political Science Review, 95:1.

Keohane, R. (1988) 'International institutions: Two approaches', International Studies Quarterly, 32:4.

Kirchner, E. J. (2007) 'EU: The European Security Strategy versus national preferences', in E. J. Kirchner and J. Sperling (eds), Global Security Governance: Competing Perceptions of Security in the 21st Century (London: Routledge).

Kirchner, E. J. (2006) 'The challenge of European Union security governance', Journal of Common Market Studies, 44:5.

Kirchner, E. J. and Sperling, J. (eds) (2007) Global Security Governance: Competing Perceptions of Security in the 21st Century (London: Routledge).

Kirchner, E. J. and Sperling, J. (2002) 'The new security threats in Europe: Theory and evidence', European Foreign Affairs Review, 7:4.

Knaus G. and Cox, M. (2004) 'Bosnia and Herzegovina: Europeanisation by decree', Chaillot Paper, 70 (Paris: Institute for Security Studies).

Koremenos, B., Lipson, C. and Snidal, D. (2001) 'The rational design of international institutions', International Organization, 55:4.

Krahmann, E. (2003) 'Conceptualising security governance', Cooperation and Conflict, 38:1.

Krasner, S. D. (2001) 'Abiding sovereignty', International Political Science Review, 22:3.

Krasner, S. D. (1999) Sovereignty: Organized Hypocrisy (Princeton: Princeton University Press).

Krasner, S. D. (1995/1996) 'Compromising Westphalia', International Security, 20:3. 
Krasner, S. D. and Pascual, C. (2005) 'Addressing state failure', Foreign Affairs, $84: 4$.

Krause, K. (1998) 'Theorising security, state formation and the "third world" in the post-Cold War world', Review of International Studies, 24:1.

Laffan, B., O’Donnell, R. and Smith, M. (2000) Europe's Experimental Union: Rethinking Integration (London: Routledge).

Langer, W. L. (1950) European Alliances and Alignments (New York: Random House, 2nd edn).

Lehne, S. (2004) 'Has the "hour of Europe" come at last? The EU's strategy for the Balkans', Chaillot Paper, 70 (Paris: Institute for Security Studies).

Leonard, M. and Gowan, R. (2004) 'Global Europe: Implementing the Security Strategy', Foreign Policy Centre Articles, available at http://fpc.org.uk/fsblob/ 187.pdf (accessed 7 August 2006).

Lindley-French, J. (2002) 'In the shade of Locarno: Why European defence is failing', International Affairs, 78:4.

Lindstrom, G. (2005) 'EU-US burdensharing: Who does what', EU-ISS Chaillot Paper, 82 (Paris: Institute for Security Studies).

Lindstrom, G. (2004) 'Protecting the European homeland: The CBR dimension', EU-ISS Chaillot Paper, 69 (Paris: Institute for Security Studies).

Liska, G. (1962) Nations in Alliance: The Limits of Interdependence (Baltimore: Johns Hopkins University Press).

Longhurst, K. and Zaborowski, M. (2005) Old Europe, New Europe and the Transatlantic Security Agenda (London: Routledge).

Lynch, D. (2003) 'The South Caucasus: A challenge for Europe', Chaillot Paper, 65 (Paris: Institute for Security Studies).

Macdonald, N. and Wagstyl, S. (2007) 'UN's Kosovo compromise leaves both sides frustrated', Financial Times 13 February 2007.

Macfarlane, N. (2004) 'The Caucasus and Central Asia: Towards a non-strategy', in R. Dannreuther (ed.), European Union Foreign and Security Policy: Towards a Neighbourbood Strategy (London: Routledge).

March, J. G. and Olsen, J. P. (1998) 'The institutional dynamics of international political orders', International Organization, 52:4.

Martenczuk, B. (2000) 'From Lomé to Cotonou: The ACP-EC Partnership Agreement in a legal perspective', European Foreign Affairs Review, 5:4.

Martin, L. L. and Simmons, B. A. (1998) 'Theories and empirical studies of international institutions', International Organization, 52:4.

Matlary, J. H. (2006) 'When soft power turns hard: Is an EU strategic culture possible?', Security Dialogue, 27:1.

Maull, H. W. (2005) 'Europe and the new balance of global order', International Affairs, 81:4.

Meiers, F.-J. (1999) 'A German defence review', in G. Wilson (ed.), European Force Structures, Occasional Paper, 8 (Paris: Institute for Security Studies).

Menon, A. (2003) 'Why ESDP is misguided and dangerous to the Alliance', in J. Howorth and J. T. S. Keeler (eds), Defending Europe: The EU, NATO and the Quest for European Autonomy (Basingstoke: Palgrave). 
Merlinger, M. and Ostrauskaite, R. (2005) 'ESDP police missions: Meaning, context and operational challenges', European Foreign Affairs Review, 10:2.

Meyer, C. O. (2005) 'Convergence towards a European Strategic Culture? A constructivist framework for explaining changing norms', European Journal of International Relations, 11:4.

Ministry of Defence (2003) 'Delivering security in a changing world: Defence white paper', London, December 2003, cmnd 6041.

Ministry of Defence (2002) 'The Strategic Defence Review: A new chapter, Volume 1', London, July 2002, cmnd 5566.

Ministry of Defence (1998) 'Strategic Defence Review', July 1998, cmnd3999, available at www.mod.uk/DefenceInternet/AboutDefence/CorporatePublications/ PolicyStrategyandPlanning/StrategicDefenceReview.htm (accessed 17 August 2006).

Missiroli, A. (2004) 'The EU and its changing neighbourhood: Stabilization, integration and partnership', in R. Dannreuther (ed.), European Union Foreign and Security Policy: Towards a Neighbourhood Strategy (London: Routledge).

Missiroli, A. (ed.) (2003a) 'From Copenhagen to Brussels. European defence: Core documents, vol. III', Chaillot Paper, 67 (Paris: Institute for Security Studies).

Missiroli, A. (2003b) 'Ploughshares into swords? More euros for European defence', European Foreign Affairs Review, 8:1.

Mitrakas, A. (2006) 'Information security and law in Europe: Risks checked?', Information and Communications Technology Law, 15:1.

Monaco, A. (2004) 'Bosnia: The litmus-test for the NATO-EU strategic relationship?', ISIS Europe, 6:2.

Monar, J. (2004) 'Justice and Home Affairs', Journal of Common Market Studies, 42: Annual Review.

Mörth, U. and Britz, M. (2004) 'European integration as organizing: The case of armaments', Journal of Common Market Studies, 52:5.

Most, B. A. and Starr, H. (1980) 'Diffusion, reinforcement, geopolitics, and the spread of war', American Political Science Review, 74:4.

Müller-Wille, B. (2004) 'For our eyes only? Shaping an intelligence community with the EU', Occasional Paper, 50 (Paris: Institute for Security Studies).

NATO (2003a) 'Table 3: Defence Expenditures as \% of Gross Domestic Product', available at www.nato.int/docu/pr/2003/table3.pdf (accessed 17 November 2004).

NATO (2003b) 'Table 5. Distribution of Total Defence Expenditures by Category', available at www.nato.int/docu/pr/2003/table5.pdf (accessed 17 November 2004).

NATO (2002) 'Statement on capabilities', 6 June 2002, press release (2002)074.

North Atlantic Council (1999) 'The alliance strategic concept', Washington, DC, 23-24 April.

North Atlantic Council (1991), 'The new strategic concept', Rome, 7-8 November. 
Nuttall, S. (2005) 'Coherence and consistency', in C. Hill and M. Smith (eds), International Relations and the European Union (Oxford: Oxford University Press).

Nuttal, S. (1992) European Political Cooperation (Oxford: Clarendon).

Ojanen, H. (2006) 'The EU and the UN: A shared future', FIIA Report, 13.

Ortega, M. (2005) 'The European Union and the United Nations: Partners in effective multilateralism', Chaillot Paper, 78 (Paris: Institute for Security Studies).

OSCE (1999) 'Istanbul Document: Charter for European Security', Istanbul, November 1999, available at www.osce.org/documents/mcs/1999/11/4050_ en.pdf (accessed 23 June 2004).

Osgood, R. E. (1962) NATO: The Entangling Alliance (Chicago: University of Chicago Press).

Osiander, A. (2001) 'Sovereignty, international relations, and the Westphalian myth', International Organization, 55:2.

Paris, R. (2004) At War's End: Building Peace after Civil Conflict (Cambridge: Cambridge University Press).

Paterson, W.E. (2006) 'Germany: Does it still have a European avocation?', paper delivered at the 2006 annual meeting of the American Political Science Association, Philadelphia, PA, 30 August-3 September.

Pentland, C. (2000) 'Westphalian Europe and the EU's last enlargement', Journal of European Integration, 22:3.

Pippan, C. (2004) 'The rocky road to Europe: The EU's stabilisation and association process for the Western Balkans and the principle of conditionality', European Foreign Affairs Review, 9:2.

Plate, B. von (2003) Die Zukunft des transatlantischen Verhältnisses: Mehr als die NATO (Berlin: Stiftung Wissenschaft und Politik).

Posch, W. (ed.) (2005) 'Looking into Iraq', Chaillot Paper, 79 (Paris: Institute for Security Studies).

Powell, R. (1991) 'Absolute and relative gains in international relations theory', American Political Science Review, 85:4.

Quille, G. (2004) 'The European Security Strategy: A framework for EU security interest?', International Peacekeeping, 11:3.

Ramboll Management (2005) 'Ex post evaluation of Grotius II, Oisin II, STOP II, Falcone and Hippocrates Programmes and Interim Evaluation of the AGIS programme', study commissioned by the European Commission.

Ranck, H. and Schmitt, B. (2005) 'Threat assessment', in B. Schmitt (ed.), 'Information security: A new challenge for the EU', Chaillot Paper, 76 (Paris: Institute for Security Studies).

Rees, W. and Aldrich, R. J. (2005) 'Contending cultures of counterterrorism: Transatlantic divergence or convergence?', International Affairs, 81:5.

Risse, T. (1995) Cooperation among Democracies. The European Influence on U.S. Foreign Policy (Princeton: Princeton University Press).

Rohde, J. and Frenzel, M. (2003) 'Transatlantic gaps and European armaments cooperation', in Prospects on the European Defence Industry (Athens: Defence Analysis Institute). 
Rosenau, J. N. (2000) 'Change, complexity, and governance in globalizing space', in J. Pierre (ed.), Debating Governance: Authority, Steering and Democracy (Oxford: Oxford University Press).

Rosenau, J. N. (1997) Along the Domestic-Foreign Frontier: Exploring Governance in a Turbulent World (Cambridge: Cambridge University Press). Rosenau, J. N. (1992) 'Governance, order, and change in world politics', in J. N. Rosenau and E.-O. Czempiel (eds), Governance without Government: Order and Change in World Politics (Cambridge: Cambridge University Press).

Ruggie, J. G. (1986) 'Continuity and transformation in the world polity: Toward a neo-realist synthesis', in R. O. Keohane (ed.), Neorealism and Its Critics (New York: Columbia University Press).

Rummel, R. (2004) 'Conflict prevention: Making EU talents work', Working Paper FG 2, 2004/3, Research Unit EU External Relations, Stiftung Wissenschaft und Politik, German Institute for International and Security Studies.

Rummel, R. and Wiedemann, J. (1998) 'Identifying institutional paradoxes of CFSP', in J. Zielonka (ed.), Paradoxes of European Foreign Policy (The Hague: Kluwer Law International).

Rusi, A. (2001) 'Europe's changing security role', in H. Gärtner, A. Hyde-Price, and E. Reiter (eds), Europe's New Security Challenges (Boulder, CO: Lynne Rienner).

Rutten, M. (ed.) (2002) 'From Nice to Laeken. European defence: Core documents, vol. II', Chaillot Paper, 51 (Paris: Institute for Security Studies).

Rutten, M. (ed.) (2001) 'From St.-Malo to Nice. European defence: Core documents', Chaillot Paper, 47 (Paris: Institute for Security Studies).

Rynning, S. (2003) 'The European Union: Towards a strategic culture?', Security Dialogue, 34:4.

Saferworld International Alert (2005) 'Developing EU Strategy to Address Fragile States: Priorities for the UK Presidency of the EU in 2005', available at www.saferworld.org.uk/publications.php?id=18 (accessed 12 August 2006).

Sandler, T. (1992) Collective Action: Theory and Application (New York: Harvester Wheatsheaf).

Schmitt, B. (2005) Defence Expenditures (Paris: ISS).

Schweller, R. (1998) Deadly Imbalances: Tripolarity and Hitler's Strategy of World Conquest (New York: Columbia University Press).

Secretary of Defense (2003) 'Report on allied contributions to the common defense', Washington, DC, July 2003.

Shelley, L. I. (2003) 'Organized crime, terrorism and cybercrime', in H. Born, M. Caparini and P. Fluri (eds), Security Sector Reform: Institutions, Society and Good Governance (Baden-Baden: Nomos Verlag).

SIPRI (2006) 'Appendix. Table 8B: Military Expenditure, by Category', available at http: //yearbook2006.sipri.org/chap8/app8b (accessed 20 August 2006).

SIPRI (2003) SIPRI Yearbook 2003: Armaments, Disarmament and International Security (London: Oxford University Press).

Siverson, R. M. and Starr, H. (1990) 'Opportunity, willingness, and the diffusion of war', American Political Science Review, 84:1. 
Smith, H. (1998) 'Actually existing foreign policy - or not? The EU in Latin and Central America', in J. Peterson and H. Sjursen (eds), A Common Foreign Policy for Europe? Competing Visions of the CFSP (London: Routledge).

Smith, K. E. (2005) 'The outsiders: The European Neighbourhood Policy', International Affairs, 81:4.

Smith, K. E. (1998) 'The use of political conditionality in the EU's relations with third countries: How effective?', European Foreign Affairs Review, 3:2.

Smith, M. (2005) 'Implementation: Making the EU's international relations work', in C. Hill and M. Smith (eds), International Relations and the European Union (Oxford: Oxford University Press).

Smith, M.E. (2004) Europe's Foreign and Security Policy: The Institutionalization of Cooperation (Cambridge, Cambridge University Press).

Smith, M. (2003) 'The framing of European foreign and security policy: Towards a post-modern policy framework?', Journal of European Public Policy, 10:4.

Snyder, G. H. (1991) 'Alliances, balance, and stability', International Organization, 45:1.

Solana, J. (2004) ' "Remarks", at the informal meeting of defence ministers', Brussels, 5-6 April 2004, S0097/04.

Solana, J. (2003a) A Secure Europe in Better World: European Security Strategy (Brussels: European Union Institute for Security Studies).

Solana, J. (2003b) 'The EU security strategy: Implications for Europe's role in a changing world', EUHR Speech, Berlin, 12 November 2003, available at www. foreignpolicy.org.tr/documents/solana_121103_p.htm (accessed 14 August 2006).

Sperling, J. (2007) 'State attributes and system properties: Security multilateralism in Central Asia, Southeast Asia, the Atlantic and Europe', in D. Bourantonis, K. Ifantis and P. Tsakonas (eds), Multilateralism and Security Institutions in an Era of Globalization (London: Routledge).

Sperling, J. (2006) 'Capabilities gaps and traps: Symptoms or cause of a troubled Atlantic relationship?', in M. A. Smith (ed.), Where Is NATO Going? (London: Routledge).

Sperling, J. (2004) 'The foreign policy of the Berlin Republic: The very model of a post-modern major power?', German Politics, 12:3.

Sperling, J. (2003) 'Eurasian security governance: New threats, institutional adaptations', in J. Sperling, S. Kay and S. V. Papacosma (eds), Limiting Institutions? The Challenge of Eurasian Security Governance (Manchester: Manchester University Press).

Sperling, J. (2001a) 'The United States: Strategic vision or tactical planning?', in M. A. Smith and G. Timmins (eds), Uncertain Europe: Building a New European Security Order? (London: Routledge).

Sperling, J. (2001b) 'European Union foreign policy: Still an oxymoron?', in S. W. Hook (ed.), Comparative Foreign Policy: Adaptation Strategies of the Great and Emerging Powers (New York: Prentice Hall).

Sperling, J. and E. Kirchner (1998) 'Economic security and the problem of cooperation in post Cold War Europe', Review of International Studies, 24:2. 
Sperling, J. and E. Kirchner (1997) Recasting the European Order: Security Architectures and Economic Cooperation (Manchester: Manchester University Press).

Stålenheim, P. (2003) 'Appendix.Table 10B: NATO military expenditure, by category', SIPRI Yearbook 2003.

Tanner, F. (2004) 'North Africa: Partnership, exceptionalism and neglect', in R. Dannreuther (ed.), European Union Foreign and Security Policy: Towards a Neighbourhood Strategy (London: Routledge).

Tardy, T. (2005) 'EU-UN cooperation in peacekeeping: A promising relationship in a constrained environment, Chaillot Paper, 78 (Paris: Institute for Security Studies).

Taylor, A. J. P. (1954) The Struggle for Mastery of Europe, 1848-1918 (Oxford: Clarendon Press).

Tegnell, A., Bossi, P., Baka, A., Van Loock, F., Hendriks, J., Wallyn, S. and Gouvras, G. (2003) 'The European Commission's task force on bioterrorism', Emerging Infectious Diseases, 9:10.

Tovias, A. and Ugur, M. (2004) 'Can the EU anchor policy reform in third countries? An analysis of the Euro-Med Partnership', European Union Politics, 5:4.

UK Parliament Select Committee on Defence (2002) 'Seventh Report', available at www.publications.parliament.uk/pa/cm200102/cmselect/cmdfence/914/ 91402.htm (accessed 17 August 2006).

UK Parliament Select Committee on Defence (1999) 'Joint Declaration Launching European Defence Capabilities Initiative, UK-Italian Summit', 19-20 July 1999, available at www.publications.parliament.uk/pa/cm199900/cmselect/ cmdfence/264/26422.htm (accessed 16 August 2006).

UN (1999) 'International Convention for the Suppression of the Financing of Terrorism', available at www.un.org/law/cod/finterr.htm (accessed 28 August 2006).

US Department of State (2000) 'Cumulative expenditures (FY 1992 to date) for major NIS assistance programs by country as of 9/30/00'.

USA Today (2005) 'Iran seeks talks with Europe on uranium', USA Today, 14 August 2005.

US-CREST (2002) 'Future military coalitions: The transatlantic challenge. Report of a French-German-UK-US Working Group' (Arlington, VA: US-CREST).

Wæver, O. (1998) 'Security, insecurity and asecurity', in E. Adler and M. N. Barnett (eds), Security Communities (Cambridge: Cambridge University Press). Wæver, O. (1995) 'Securitization and desecuritization', in R. Lipschutz (ed.), On Security (New York: Columbia University Press).

Wallace H. and Wallace, W. (1997) Policy-making in the European Union (Oxford: Oxford University Press).

Wallensteen, P. and Sollenberg, M. (2001) 'Armed conflict, 1989-2000', Journal of Peace Research, 38:5.

Walt, S. (1987) The Origins of Alliances (Ithaca: Cornell University Press). 
Waltz, K. (1978) Theory of International Politics (New York: Random House). Webber, M. (2002) 'Security governance and the "excluded" states of Central and Eastern Europe', in A. Cottey and D. Averre (eds), Ten Years after 1989: New Security Challenges in Central and Eastern Europe (Manchester: Manchester University Press).

Webber, M. (2000) 'A tale of a decade: European security governance and Russia', European Security, 9:2.

Webber, M., Croft, S., Howorth, J., Terriff, T. and Krahmann, E. (2004) 'The governance of European security', Review of International Studies, 30:1.

Weiler, J. H. H. (1991) 'The Transformation of Europe', Yale Law Journal, 100: 2403-83.

Wendt, A. (1994) 'Collective identity formation and the international state', American Political Science Review, 88:2.

WEU Council of Ministers (1999) 'WEU Audit of Assets and Capabilities for European Crisis Management Operations: Recommendations for strengthening European capabilities for crisis management operations', Luxembourg, 22-3 November 1999, available at www.weu.int/documents/991122en.pdf (accessed 16 August 2006).

WEU Council of Ministers (1992) 'Petersberg Declaration', Bonn, 19 June 1992, available at www.weu.int/documents/920619peten.pdf (accessed 16 August 2006).

Wogau, K. von (ed.) (2005) 'The Path to European Defence', available at www.european-defence.co.uk/directory/althea/html (accessed 2 March 2005).

Wolfers, A. (1963) 'Integration in the west: The conflict of perspectives', International Organisation, 17:3, 753-70.

Wolfers, A. (ed.) (1959) Alliance Policy in the Cold War (Baltimore: Johns Hopkins University Press.

World Bank (2000) 2000 World Development Indicators (Washington, DC: World Bank).

Young, O. R. (1999) Governance in World Affairs (Ithaca: Cornell University Press).

Youngs, R. (2004) 'Democratic institution-building and conflict resolution: Emerging EU approaches', International Peacekeeping, 11:3.

Youngs, R. (2003) 'European approaches to democracy assistance: Learning the right lessons?', Third World Quarterly, 24:1.

Youngs, R. (2001) 'Democracy promotion: The case of European Union strategy', Centre for European Policy Studies Working Document, 167.

Ypersele de Strihou, J. van (1967) 'Sharing the defense burden among Western allies', Review of Economics and Statistics, 49:4.

Zanger, S. C. (2000) 'Good governance and European aid: The impact of political conditionality', European Union Politics, 1:3.

Zellner, W. (2002) 'The OSCE: Uniquely qualified for a conflict-prevention role', in P. van Tongeren, H. van de Veen and J. Verhoeven (eds), Searching For Peace in Europe and Eurasia: An Overview Of Conflict Prevention And Peacebuilding Activities (Boulder, CO: Lynne Rienner). 


\section{EU official documents}

Article 36 Committee (2002) 'Terrorist activity in the European Union: Situation and trends', 20 February 2002, 5759/1/02 REV 1 ENFOPOL 21, DG H II.

Article 36 Committee (1999) 'Finalisation and evaluation of the Action Plan on Organised Crime: Draft Report to the Helsinki European Council', 9917/3/99 Rev 3, DG H III, 12 November 1999.

Conference of the Representatives of the Governments of the Member States (2004) 'Treaty establishing a Constitution for Europe', CIG 87/2/04 REV 2, 29 October 2004.

Council of the European Union (2006) 'Brussels European Council 15/16 December 2005 Presidency conclusions', 15914/05, 30 January.

Council of the European Union (2006) 'Capabilities Improvement Chart I/2006', available at www.consilium.europa.eu/cms3_fo/showPage.asp?id=437\&lang= $\mathrm{EN} \&$ mode $=\mathrm{g}$ (accessed 15 August 2006).

Council of the European Union (2006) 'EU military operation in support of the MONUC during the election process in the RD Congo', 10366/06 (Presse 180), Luxembourg, 12 June.

Council of the European Union (2006) 'Presidency Report on ESDP', 10418/06, 12 June.

Council of the European Union (2005) 'Brussels European Council 16 and 17 June 2005, Presidency Conclusions', 10255/05 CONCL 2, 18 June.

Council of the European Union (2005) 'Council Decision 2005/681/JHA of 20 September 2005 establishing the European Police College (CEPOL) and repealing Decision 2000/820/JHA', OJ L 256/63.

Council of the European Union (2005) 'Council Decision 2005/395/CFSP of 10 May 2005 amending Decision 2001/80/CFSP on the establishment of the Military Staff of the European Union', OJ L 132/18.

Council of the European Union (2005) 'Council Framework Decision 2005/222/JHA of 24 February 2005 on attacks against information systems', OJ L 69/67, 16 March.

Council of the European Union (2005) 'Council Framework Decision 2005/214/JHA of 24 February 2005 on the application of the principle of mutual recognition to financial penalties', OJ L 76/16, 22 March.

Council of the European Union (2005) 'Draft Directive of the European Parliament and of the Council on the prevention of the use of the financial system for the purpose of money laundering and terrorist financing', 10245/05, 17 June.

Council of the European Union (2005) 'Directive 2005/60/EC of the European Parliament and of the Council of 26 October 2005 on the prevention of the use of the financial system for the purpose of money laundering and terrorist financing', OJ L 309/15, 25 November.

Council of the European Union (2005) 'Fight against terrorism: six monthly report', 1477/05 LIMITE, 21 November. 
Council of the European Union (2005) 'Final report on the evaluation of national anti-terrorist arrangements: Improving national machinery and capability in the fight against terrorism', 12168/3/05, 18 November.

Council of the European Union (2005) 'Implementation of the Action Plan to combat terrorism', 14734/1/05 REV 1, 29 November.

Council of the European Union (2005) 'Joint Statement by the Council and the representatives of the governments of the member states meeting within the Council, the European Parliament and the Commission on European Union development policy: "The European consensus"', 14820/05, 22 November.

Council of the European Union (2005) 'Press Release 2660th Council meeting, General Affairs and External Relations', Brussels, 23 and 24 May 2005, Presse $8817 / 05$.

Council of the European Union (2005) 'Press Release 2655 th Council meeting, General Affairs and External Relations', Luxembourg, 25 April 2005, Presse $868035 / 05$.

Council of the European Union (2005) 'Press Release 2650 th Council meeting, General Affairs and External Relations', Brussels, 16 March 2005, Presse 45 6970/05.

Council of the European Union (2005) 'Prüm Convention', 10900/05, LIMITE, 7 July.

Council of the European Union (2005) 'The European Union Counter-terrorism Strategy', 14469/4/05 REV 4 LIMITE, Brussels 30 November 2005.

Council of the European Union (2004) 'Annex. Strengthening of states' capabilities for detection and response to illicit trafficking' in 'Council Joint Action 2004/495/CFSP of 17 May 2004 on support for IAEA activities under its Nuclear Security Programme and in the framework of the implementation of the EU strategy against proliferation of weapons of mass destruction', OJ L 182/46.

Council of the European Union (2004) 'Brussels European Council, 4/5 November 2004, Presidency Conclusions', 14292/04, CONCL 3, 5 November.

Council of the European Union (2004) 'CEPOL Annual Work Programme for 2005', 10058/04, 8 June.

Council of the European Union (2004) 'Council Decision 2004/803/CFSP of 25 November 2004 on the launching of the European Union military operation in Bosnia and Herzegovina', OJ L 353/21, 27 November.

Council of the European Union (2004) 'Council Decision 2004/197/CFSP of 23 February 2004', OJ L 63/68, 28 February.

Council of the European Union (2004) 'Council Joint Action 2004/551/CFSP of 12 July 2004 on the establishment of the European Defence Agency', OJ L 245/17, 17 July.

Council of the European Union (2004) 'Draft Framework Decision on simplifying the exchange of information and intelligence between law enforcement authorities of the member states of the European Union, in particular as regards serious offenses including terrorist acts', 13869/04, 11 April. 
Council of the European Union (2004) 'EU Solidarity Programme on the consequences of terrorist threats and attacks (revised/widened CBRN Programme): Adoption', 15480/04, 1 December.

Council of the European Union (2004) 'EU strategy against proliferation of weapons of mass destruction: Draft Progress Report on the implementation of Chapter III of the strategy', 10448/04, 10 June.

Council of the European Union (2004) 'Presidency conclusions, Annex I (The Hague Programme: Strengthening freedom, security and justice in the European Union)', 14292/04 CONCL 3, 4-5 November.

Council of the European Union (2004) 'Press Release. 2606 ${ }^{\text {th }}$ Council Meeting', 12400/04 (Presse 264), 4 October.

Council of the European Union (2004) 'Regulation (EC) no. 851/2004 of the European Parliament and of the Council of 23 April 2004 establishing a European Centre for disease prevention and control', OJ L 142/1, 30 April.

Council of the European Union (2004) 'Regulation (EC) no. 460/2004 of the European Parliament and of the Council of 10 March 2004 establishing the European Network and Information Security Agency', OJ L 77/1, 13 March.

Council of the European Union (2003) 'Action Plan for the implementation of the basic principles for an EU strategy against proliferation of weapons of mass destruction', 10 June, in A. Missiroli, 'From Copenhagen to Brussels. European Defence: Core documents, vol. IV', Chaillot Paper, 67 (Paris: Institute for Security Studies, 2003).

Council of the European Union (2003) 'Council Decision 2003/874/CFSP of 8 December 2003 implementing Joint Action 2003/472/CFSP with a view to contributing to the European Union cooperation programme for nonproliferation and disarmament in the Russian Federation', OJ L 326/49, 13 December.

Council of the European Union (2003) 'Council Common Position 2003/805/CFSP of 17 November 2003 on the universalisation and reinforcement of multilateral agreements in the field of nonproliferation of weapons of mass destruction and means of delivery', OJ L 302/34, 20 November.

Council of the European Union (2003) 'Council Decision 2003/567/CFSP of 21 July 2003 implementing Common Position 1999/533/CFSP relating to the European Union's contribution to the promotion of the early entry into force of the Comprehensive Nuclear Test-Ban Treaty (CTBT)', OJ L 192/53, 31 July.

Council of the European Union (2003) 'Council Decision 2003/563/CFSP of 29 July 2003 on the extension of the European Union military operation in the Former Yugoslav Republic of Macedonia', OJ L 190/20, 30 July.

Council of the European Union (2003), ' Council Decision 2003/48/JHA of 19 December 2002 on the implementation of specific measures for police and judicial cooperation to combat terrorism in accordance with Article 4 of Common Position 2001/931/CFSP', OJ L 16/68, 22 January. 
Council of the European Union (2003) 'Council Framework Decision 2003/577/JHA of 22 July 2003 on the execution of orders freezing property or evidence', OJ L 196/45, 2 August.

Council of the European Union (2003) 'Council Joint Action 2003/92/CFSP of 27 January 2003 on the European Union military operation in the Former Yugoslav Republic of Macedonia', OJ L 34/26, 11 February.

Council of the European Union (2003) 'European Defence Meeting: Conclusions', Egmont Palace, 29 April 2003, available at www.foreignpolicy. org/tr/eng/eu/egmontpalace_290403.htm (accessed 15 December 2004).

Council of the European Union (2003) 'Europol work programme 2004', 8580/03 LIMITE, 28 April.

Council of the European Union (2003) 'Programme of measures to combat illegal immigration across the maritime borders of the member states of the European Union', 15445/03, LIMITE, 28 November.

Council of the European Union (2003) 'Report on the measures and steps taken with regard to the implementation of the recommendations of the European Union strategy for the beginning of the new millennium on prevention and control of organised crime', 10925/03 LIMITE, 30 June.

Council of the European Union (2002) 'Adoption of the programme to improve cooperation in the European Union for preventing and limiting of chemical, biological, radiological or nuclear terrorist threats', 14627/02, 21 November.

Council of the European Union (2002) 'Council Decision 2002/630/JHA of 22 July 2002 establishing a framework programme on police and judicial cooperation in criminal matters (AGIS)', OJ L 203/5, 1 August.

Council of the European Union (2002) 'Council Decision of 13 June 2002 adopting an action programme for administratived cooperation in the fields of external borders, visas, asylum and immigration (ARGO programme)', OJ L 161/11, 19 June.

Council of the European Union (2002) 'Council Framework Decision of 13 June 2002 on joint investigation teams' (2002/465/JHA), OJ L 162/1, 13 June.

Council of the European Union (2002) 'Council Framework Decision 2002/584/JHA of 13 June 2002 on the European arrest warrant and the surrender procedures between member states', OJ L 190, 18 July.

Council of the European Union (2002) 'Council Framework Decision 2002/475/JHA of 13 June 2002 on combating terrorism', OJ L 164/3, 22 June.

Council of the European Union (2002) 'Europol Annual Report 2001', 8381/02 LIMITE, 30 April.

Council of the European Union (2001) 'Annex. Protocol established by the Council in accordance with Article 34 of the Treaty on European Union to the Convention on Mutual Assistance in Criminal Matters between the Member States of the European Union (2001/C/01)', OJ C 326/2, 21 November.

Council of the European Union (2001) 'Common Position on combating terrorism' (2001/93/CFSP) in M. Rutten (ed.), 'From Nice to Laeken. European Defence: core documents, Vol. II', Chaillot Paper, 51 (Paris: Institute for Security Studies, 2002). 
Council of the European Union (2001) 'Council Common Position of 27 December 2001 on the application of specific measures to combat terrorism' (2001/931/CFSP), available at http: //europa.eu/eur-lex/pri/en/oj/dat/2001/1_ 344/1_34420011228en00930096.pdf (accessed 28 August 2005).

Council of the European Union (2001) 'Council Decision of 28 June 2001 establishing a second phase of the programme of incentives and exchanges, training and cooperation for legal practitioners (Grotius II-Criminal)', OJ L 186/1, 7 July.

Council of the European Union (2001) 'Council Decision 2001/493/CFSP of 25 June 2001 implementing Joint Action 1999/878/CFSP with a view to contributing to the European Union Cooperation Programme for NonProliferation and Disarmament in the Russian Federation', OJ L 280/2, 3 July. Council of the European Union (2001) 'Council Framework Decision 2001/500/JHA of 26 June 2001 on money laundering, the identification, tracing, freezing, seizing and confiscation of instrumentalities and the proceeds from crime', OJ L 182/1, 5 July.

Council of the European Union (2001) 'Initiative of the Kingdom of Belgium, the French Republic, the Kingdom of Spain and the United Kingdom with a view to adopting a Council Framework Decision on joint investigation teams', (2001/C 295/06), OJ C 259/9, 20 October.

Council of the European Union (2000) 'Adoption of Action Plan for Albania and the region' and 'Implementation of the Action Plans for Afghanistan and the region, Iraq, Morocco, Somalia and Sri Lanka', 8939/00 LIMITE, 30 May.

Council of the European Union (2000) 'Council Decision of 17 October 2000 concerning arrangements for cooperation between financial intelligence units of the Member States in respect of exchanging information', OJ L, 27/4, 24 October.

Council of the European Union (2000) 'Explanatory report on the Convention of 29 May 2000 on Mutual Assistance in Criminal Matters between the Member States of the European Union' (2000/C 379/02), OJ C 379/7, 29 December.

Council of the European Union (2000) 'High Level Working Group on asylum and migration: Adoption of the report to the European Council in Nice', 13993/00 LIMITE, 29 November.

Council of the European Union (2000) 'Implementation of the action plans for Afghanistan and the region, Iraq, Morocco, Somalia and Sri Lanka', 8939/00 LIMITE, 30 May.

Council of the European Union (1999) 'Council recommendation of 9 December 1999 on cooperation in combating the financing of terrorist groups' (1999/373/01), OJ C 373/1, 23 December.

Council of the European Union (1999) 'Joint Action of 3 December 1998 adopted by the Council on the basis of Article K.3 of the Treaty on European Union, on money laundering, the identification, tracing, freezing, seizing and confiscation of instrumentalities and the proceeds of crime' (98/699/JHA), OJ L 331/1, 9 December. 
Council of the European Union (1999) 'Joint position of 29 March 1999 defined by the Council on the basis of Article K.3 of the Treaty on European Union, on the proposed United Nations convention against organised crime' (1999/235/JHA), OJ L 87/1, 31 March.

Council of the European Union (1999) 'Progress report on the proceedings of the High Level Working Group on asylum and migration', 9197/99 LIMITE, 11 June.

Council of the European Union (1999) 'Towards a union of freedom, security and justice: The Tampere milestones', Tampere European Council, 15-16 October.

Council of the European Union (1999) 'Council Joint Action of 17 December 1999 establishing a European Union Cooperation Programme for Nonproliferation and Disarmament in the Russian Federation (1999/878/CFSP)', OJ L, 331/11, 23 December.

Council of the European Union (1998) 'Joint Action of 29 June 1998 adopted by the Council on the basis of Article K.3 of the Treaty on European Union, on the creation of a European judicial network', (98/428/JHA)', OJ L 191/4, 7 July.

Council of the European Union (1994) 'Council Decision of November 1994 appointing an ombudsman for Mostar for the duration of the European Union administration of Mostar' (94/776/EC), OJ L 312/34, 6 December.

ENISA (2005) ENISA General Report 2005 (Brussels: Enisa).

EU Operations (2006) 'Factsheet, EU police mission in Bosnia and Herzegovina', available at www.consilium.europa.eu/cms3 (accessed 1 March 2006).

'EU-US Declaration on Combating Terrorism', Dromoland Castle, 26 June 2004.

Eurojust (2006) Annual Report 2005 (The Hague: Eurojust).

Eurojust (2005) Annual Report 2004 (The Hague: Eurojust).

Eurojust (2004) Annual Report 2003 (The Hague: Eurojust).

Eurojust (2003) Annual Report 2002 (The Hague: Eurojust).

Euronews (2006) 'History Is Made as DR Congo Holds Elections', available at www.euronews.net (accessed 31 July 2006).

Europe Aid Cooperation Office (2006) 'European Initiative for Democracy and Human Rights (EIDHR) Programming and Annual Work Programme for 2005 and 2006', available at http: //europa.eu.int/comm/europeaid/projects/eidhr/ documents_en.htm\#eidhr (accessed 14 August 2006).

European Agency for Reconstruction (2004) 'Annual Report to the European Parliament and the Council, January to December 2003', Thessaloniki, 7 June 2004, available at www.ear.eu.int/publications/main/documents/ EARAnnualReport2003.pdf (accessed 12 August 2006).

European Centre for Disease Prevention and Control (2005) 'Programme of work for 2005-2006', Reference MB2/9, 4 February.

European Commission (2006) 'Communication from the Commission to the Council and the European Parliament: Evaluation of EU policies on freedom, security and justice', $\operatorname{COM}(2006) 332$ final, 26 June. 
European Commission (2006) 'Communication from the Commission to the Council and the European Parliament. Implementing The Hague Programme: The way forward', $\operatorname{COM(2006)~} 331$ final, 28 June.

European Commission (2006) 'Communication from the Commission to the European Parliament and the Council on judicial training in the European Union', COM(2006) 356 final, 29 June.

European Commission (2006) 'Report from the Commission: Second Commission report based on Article 6 of the Council Framework Decision of 26 June 2001 on money laundering, the identification, tracing, freezing, seizing and confiscation of instrumentalities and the proceeds of crime', COM (2006) 72 final, 21 February.

European Commission (2006) 'Commission simplifies external cooperation programmes', Europa-Rapid-Press Releases Reference, Brussels, 25 January, IP/06/82.

European Commission (2005) 'Commission staff working document. Revised Action Plan on terrorism: Update June 2005', SEC(2005) 841, 17 June.

European Commission (2005) 'Commission Staff Working Document: Second annual report to the European Parliament and the Council on the implementation of the AGIS programme, Year 2004', SEC(2005) 1764, 15 December.

European Commission (2005) 'Commission staff working paper Annex to: "European neighbourhood policy”, country report Armenia', SEC(2005) 285/3, 2 March.

European Commission (2005) 'Commission staff working paper Annex to: "European neighbourhood policy”, country report Azerbaijan', SEC(2005) 286/3, 2 March.

European Commission (2005) 'Commission staff working paper Annex to: “European neighbourhood policy”, country report Egypt', SEC(2005) 287/3, 2 March.

European Commission (2005) 'Commission staff working paper Annex to: "European neighbourhood policy”, country report Georgia', SEC(2005) 288/3, 2 March.

European Commission (2005) 'Commission staff working paper Annex to: “European neighbourhood policy”, country report Lebanon', SEC(2005) 289/3, 2 March.

European Commission (2005) 'Commission staff working paper. Annex to: the Report from the Commission on national measures taken to comply with the Council Framework Decision of 13 June 2002 on joint investigation teams', SEC (2004) 1725, 1 July.

European Commission (2005) 'Communication from the Commission to the Council and the European Parliament: Developing a strategic concept on tackling organized crime', $\operatorname{COM(2005)} 232$ final, 2 June.

European Commission (2005) 'Communication from the Commission to the Council and the European Parliament on improved effectiveness, enhanced interoperability and synergies among European databases in the area of Justice and Home Affairs', COM (2005) 597 final, 24 November. 
European Commission (2005) 'Communication from the Commission to the Council and the European Parliament on the mutual recognition of judicial decisions in criminal matters and the strengthening of mutual trust between Member States', COM(2005) 195 final, 19 May.

European Commission (2005) 'Communication from the Commission to the European Parliament, the Council, the European Economic and Social Committee and the Committee of the Regions: Commission provisions on “ARGUS” general rapid alert system', COM(2005) 662 final, 23 December.

European Commission (2005) 'Communication on measures to ensure greater security of explosives, detonators, bomb-making equipment and firearms', $\operatorname{COM}(2005) 329$ final, 18 July.

European Commission (2005) 'Communication on the mutual recognition of judicial decisions in criminal matters and the strengthening of mutual trust between member states', $\operatorname{COM(2005)~} 195$ final, 19 May.

European Commission (2005) 'Green Paper on a European programme for critical infrastructure protection', $\operatorname{COM}(2005) 576$ final, 17 November.

European Commission (2005) 'Green paper on conflicts of jurisdiction and the principle of ne bis in idem in criminal proceedings', COM(2005) 696 final, 23 December.

European Commission (2005) 'Highlights: Annual report 2005 on the European Community's development policy and the implementation of external assistance in 2004', Luxembourg: Office for Official Publications of the European Communities.

European Commission (2005) 'Proposal for a Council Decision on the establishment, operation and use of the second generation Schengen information system (SIS II)', COM(2005) 230 final, 31 May.

European Commission (2005) 'Proposal for a Council Decision on the improvement of police cooperation between Member States of the European Union, especially at the internal borders and amending the Convention implementing the Schengen Agreement', 2005/0131 (CNS), 18 July.

European Commission (2005) 'Proposal for a Council Decision on the transmission of information resulting from the activities of security and intelligence services with respect to terrorist offences', COM(2005) 695 final,2005/0271 (CNS), 22 December.

European Commission (2005) 'Proposal for a Council Framework Decision on the exchange of information under the principle of availability', $\operatorname{COM}(2005)$ 490 final, 12 October.

European Commission (2005) 'Proposal for a Council Framework Decision on the exchange of information under the principle of availability', $\operatorname{COM}(2005)$ 490 final, 2005/0207, 30 June.

European Commission (2005) 'Report from the Commission based on Article 34 of the Council Framework Decision of 13 June 2002 on the European arrest warrant and the surrender procedures between Member States', COM(2005) 63 final, 23 February. 
European Commission (2004) 'Commission communication on the prevention of and fight against terrorist financing', $\operatorname{COM}(2004) 700$ final, 20 October.

European Commission (2004) 'Commission Staff Working Paper: First annual report to the Council and the European Parliament on the implementation of the ARGO programme (2002-2003)', SEC(2004) 211, 17 February.

European Commission (2004) 'Commission Staff Working Paper: The area of freedom, security and justice: Assessment of the Tampere programme and future orientations - list of the most important instruments adopted', SEC(2004) 680, 2 June.

European Commission (2004) 'Communication from the Commission: European neighbourhood policy - strategy paper', $\operatorname{COM(20054)} 0373$ final, 12 May.

European Commission (2004) 'Communication from the Commission to the Council and the European Parliament. Area of freedom, security and justice: Assessment of the Tampere programme and future orientations', COM (2004) 401 final, 2 June.

European Commission (2004) 'Communication from the Commission to the Council and the European Parliament: Critical infrastructure protection in the fight against terrorism', COM (2002) 702 final, 20 October.

European Commission (2004) 'Conceptual Framework on the ESDP Dimension of the Fight against Terrorism', 22 November 2004, available at http:// ue.eu.int/uedocs/cmsUpload/14797Conceptual_Framework_ESDP.pdf (accessed 26 August 2005).

European Commission (2004) 'Green Paper: Defence procurement', COM(2004) 608 final, 23 September.

European Commission (2004) 'Green Paper on the approximation, mutual recognition and enforcement of criminal sanctions in the European Union', COM (2004)334 final, 30 April.

European Commission (2004) 'Interim Report on the Evaluation of National Anti-Terrorist Arrangements', available at www.ue.eu.int/eudocs/cmsUpload/ Interim_Report.pdf (accessed on 17 July 2005).

European Commission (2004) 'Joint strategy paper on terrorist financing of 14 October 2004', 16089/04, 14 December.

European Commission (2004) 'Proposal for a Council Framework Decision on certain procedural rights in criminal proceedings throughout the European Union', COM(2004) 328 final, 2004/0113 (CNS), 28 April.

European Commission (2004) 'Proposal for a Council Decision on the exchange of information extracted from the criminal record', $\operatorname{COM}(2004) 664$ final, 2004/0238 (CNS), 13 October.

European Commission (2004) 'Proposal for a regulation of the European Parliament and of the Council laying down general provisions establishing a European neighbourhood and partnership instrument', 2004/0219 (COD), 29 September.

European Commission (2004) 'Reference Document for Financial and Technical Assistance to Third Countries in the Area of Migration and Asylum. ANEAS 
Programme, 2004-2006', available at http: //eu.europa.eu/comm/europeaid/ projects/eidhr/pdf/themes-migration-annexe2_en.pdf (accessed on 15 July 2006).

European Commission (2004) 'Report from the Commission: The stabilisation and association process for south east Europe: Third annual report', $\operatorname{COM}(2004)$ 202/2 final, 30 March.

European Commission (2004) 'Securing Peace and Stability for Africa: The EUfunded African Peace Facility', July 2004, available at http: //ec.europa.eu/ comm/development/body/publications/docs/flyer_peace_en.pdf (accessed 8 August 2006).

European Commission (2004) 'The Fight against Terrorism: Note by the Presidency in Association with the Counter-Terrorism Co-ordinator', available at http: //www.ue.eu.int/eudocs/cmsUpload/15523.04.pdf.

European Commission (2003) 'Commission Decision of 17 July 2003 amending Decision No. 2119/98/EC of the European Parliament and of the Council and Decision 200/96/EC as regards communicable diseases listed in those decisions and amending Decision 2002/253/EC as regards the case definitions for communicable diseases', (2003/534/EC), OJ L 184/35.

European Commission (2003) 'Commission Staff Working Paper: Fifth report of the Commission to the European Parliament and the Council on the implementation of the Title VI programmes (GROTIUS II-Criminal, STOP II, OISIN II, HIPPOCRATES and FALCONE programmes)', SEC(2003) 316, 14 March.

European Commission (2003) 'Communication from the Commission to the Council and the European Parliament on cooperation in the European Union on preparedness and response to biological and chemical agent attacks (Health Security)', COM (2003) 320 final, 2 June.

European Commission (2003) 'Communication on wider Europe-neighbourhood: A new framework for relations with our eastern and southern neighbours', $\operatorname{COM}(2003) 104$ final, 11 March.

European Commission (2003) 'Country Strategy Paper 2003-2006. Tacis National Indicative Programme 2004-2006: Georgia', 23 September.

European Commission (2003) 'European defence - industrial and market issues: Towards an EU defence equipment policy', COM(2003) 113 final, 11 March.

European Commission (2003) 'Proposal for a regulation of the European Parliament and of the Council establishing a European Centre [for Disease Prevention and Control]', COM(2003) 441 final/2, 2003/0174 (COD), 16 September.

European Commission (2003) 'Signature of the MNEPR (Multilateral Nuclear Environment Programme in the Russian Federation) 21 May 2003, in Stockholm', IP/03/724, 21 May 2003, available at http: //ec.europa.eu/comm/ external_relations/russia/intro/ip03_724.htm (accessed 28 August 2005).

European Commission (2002) 'Proposal for a comprehensive plan to combat illegal immigration and trafficking of human beings in the European Union', OJ C 142/23, 14 June. 
European Commission (2002) 'Proposal for a Council Framework Decision on attacks against information systems', (2002/0086) (CNS), COM (2002) 173 final, 19 April.

European Commission (2002) 'Commission Communication to the Council and the EP', EC(2002) 159 final, 13 February.

European Commission (2002) 'One year on: The Commission's Conflict Prevention Policy', available at http://ec.europa.eu/comm/external_relations/ cfsp/cpcm/cp/rep.htm (accessed 8 August 2005).

European Commission (2001) 'Communication from the Commission: Network and information security: Proposal for a European policy approach', $\operatorname{COM}(2001)$ 298, 6 June.

European Commission (2001) 'Communication from the Commission on conflict prevention', $\operatorname{COM(2001)~} 211$ final, 11 April.

European Commission (2001) 'Communication from the Commission to the Council and the EP: Financing of civilian crisis management operations', $\operatorname{COM}(2001) 647$ final, 28 November.

European Commission (2001) 'European Commission Action Paper in Response to the Terrorist Attacks in Madrid', MEMO/04/66, 18 March 2001, available at http: //europa.eu.int/comm/external_relations/news/2004/ip04_66.htm (accessed 28 August 2005).

European Commission (2001) 'Programme of cooperation on preparedness and response to biological and chemical agent attacks', G/FS D(2001), 17 December.

European Commission (2000) 'Communication from the Commission to the Council, the European Parliament, the Economic and Social Committee and the Committee of the Regions: Creating a safer information society by improving the security of information infrastructure and combating computerrelated crime (eEurope 2002)', $\operatorname{COM(2000)~} 890$ final, 26 January 2001.

European Commission (2000) 'The prevention and control of organised crime: A European Union strategy for the beginning of the new millennium', 2000/C 124/01, OJ C 124/1, 3 May.

European Commission (1999) 'The EU \& south-eastern Europe: The stabilisation and association process for countries of south-eastern Europe', May 26 1999, available at http: //europa.eu.int/comm/external_relations/see/SAP/index.htm (accessed 1 March 2006).

European Commission (1996) 'The EU and the issue of conflicts in Africa: Peacebuilding, conflict prevention and beyond', SEC (96) 332 final, 6 March.

European Commission, DG Enlargement (2006) 'CARDS: Financial statistics', available at http: //ec.europa.eu/enlargement/financial_assistance/cards/ statistics2002-2004_en.htm (accessed 14 August 2006).

European Commission/EuropeAid Cooperation Office DG (2004) 'Euromed Report: EU Strategic Partnership with the Mediterranean and the Middle East. Final report', Issue no. 78, 23 June 2004, available at http: //ec.europa. eu/comm/external_relations/euromed/publication.htm (accessed 8 August 2006). 
European Commission/External Relations DG (2007) 'The European Roadmap towards a Zero Victim Target: The EC Mine Action Strategy \& Multi-annual Indicative Programming 2005-2007', available at http://ec.europa.eu/comm/ external_relations/mine/intro/strat05_07.htm (accessed 21 May 2007).

European Commission/External Relations DG (2005) 'Conflict Prevention \& Civilian Crisis Management: Rapid Reaction Mechanism’, December 2005, available at http: //europa.eu.int/comm/external_relations/cpcm/rrm/index.htm (accessed 14 August 2006).

European Commission/External Relations DG (2001) 'CARDS Assistance Programme to the Western Balkans, Regional Strategy Paper, 2002-2006', available at www.reliefweb.int/library/documents/2001/ec_balkans_22oct.pdf (accessed 12 August 2006).

European Convention/Working Group VIII on Defence (2003) 'Final Report (Barnier Report)', Brussels, 16 December 2002, in J.-Y. Haine (2003) From Laeken to Copenhagen. European Defence: Core Documents, Vol. III, Chaillot Paper (Paris: Institute for Security Studies).

European Convention/Working Group VIII on Defence (2002) 'Introductory note by the Secretariat on the military capabilities which could be available to the European Union', Brussels, 20 September 2002, Working Document 1, WG VIII-WD 1.

European Council (2004) 'Council Regulation (EC) No. 2007/2004 of 26 October 2004 establishing a European Agency for the management of operational cooperation at the external borders of the member states of the European Union', OJ L 349/1, 25 November.

European Council (2004) 'Declaration on combating terrorism', 7906/04, 25 March 2004.

European Council (2003) 'A Secure Europe in a Better World: European Security Strategy', Brussels, 12 December 2003, available at http://ue.eu.int/uedocs/ cmsUpload/78367.pdf (accessed 8 August 2004).

European Council (2003) 'EU strategy against proliferation of weapons of mass destruction', 12 December 2003, in Antonio Missiroli, 'From Copenhagen to Brussels. European Defence: core documents, vol. IV', Chaillot Paper, 67 (Paris: Institute for Strategic Studies, 2003).

European Council (2002) 'Presidency conclusions. Annex V. Draft Declaration of the European Council on the contribution of CFSP, including ESDP, in the fight against terrorism', Seville European Council, 21-22 June 2002 in J.-Y. Haine (ed.), 'From Laeken to Copenhagen. European Defence: Core documents, vol. III', Chaillot Paper, 57 (Paris: Institute for Security Studies, 2003).

European Council (2001) 'Declaration by the heads of state or government of the European Union and the President of the Commission: Follow-up to the September 11 attacks and the fight against terrorism', Ghent European Council, 19 October 2001 in M. Rutten (ed.), 'From Nice to Laeken. European Defence: Core documents, vol. II', Chaillot Paper, 51 (Paris: Institute for Security Studies, 2002). 
European Council (2001) 'Laeken European Council 14 and 15 December 2001 Presidency conclusions', in M. Rutten (ed.), 'From Nice to Laeken. European Defence: Core documents, vol. II', Chaillot Paper, 51 (Paris: Institute for Security Studies, 2002).

European Council (2000) 'Presidency conclusions, Santa Maria da Feira European Council 19 and 20 June 2000', in M. Rutten (ed.), 'From St.-Malo to Nice. European defence: Core documents', Challiot Paper, 47 (Paris: Institute for Security Studies, 2001).

European Council (2000) 'Presidency conclusion, Lisbon European Council, 23 and 24 March 2000', in M. Rutten (ed.), 'From St.-Malo to Nice. European defence: Core documents', Challiot Paper, 47 (Paris: Institute for Security Studies, 2001).

European Council (2000) 'Common Strategy of the European Council of 19 June 2000 on the Mediterranean region', (2000/458/CFSP), OJ L 183/5, 22 July.

European Council (1999) 'Counter-terrorism: Report from Europol', 7514/1/99 Europol 19, REV 1, 27 May.

European Council (1999) 'Presidency Conclusion: Berlin European Council, 24 and 25 March 1999', available at www.europa.eu.int/council/off/conclu/ mar99_en.htm (accessed on 23 April 2005).

European Council (1999) 'Presidency conclusions: Helsinki European Council 10 and 11 December 1999', in M. Rutten (ed.), 'From St.-Malo to Nice. European defence: Core documents', Challiot Papers, 47 (Paris: Institute for Security Studies, 2001).

European Council (1999) 'European Council Declaration on Strengthening the European Common Policy on Security and Defence' (Cologne European Council, 3 and 4 June 1999), Internationale Politik, 1:1, 2000.

European Council (1997) 'Action Plan to combat organised crime', OJ C 251/15, 15 August.

European Council and Commission (2000) 'The European Community's development policy: Statement by the Council and the Commission on the European Community's development policy', published by the European Commission, 10 November.

European Data Protection Supervisor (2005) 'Comments on the communication of the Commission on interoperability of European databases', 3 October.

European Defence Agency (2006) '22 EU member states to take part in new European defence equipment market', Brussels, 22 May.

European Defence Agency (2006) 'National Defence R\&T Data', Brussels, 25 July 2006, available at www.eda.europa.edu/facts/National\%20Defence \% 20R\&T\%20Data.htm (accessed 26 July 2006).

European Defence Agency (2006) 'Report by the Head of the European Defence Agency to the Council', 15 May.

European Defence Agency (2005) 'The code of conduct on defence procurement of the EU member states participating in the European Defence Agency', Brussels, 21 November. 
European Judicial Training Network (2002) 'Charter adopted in Copenhagen by the General Assembly on 6 December 2002', 9 December.

European Parliament and Council (2005) 'Directive 2005/60/EC of the European Parliament and the Council of 26 October 2005 on the prevention of the use of the financial system for the purpose of money laundering and terrorist financing', OJ L, 309/15, 25 November.

European Parliament and European Council (1998) 'Decision no. 2119/98/EC of the European Parliament and European Council of 24 September 1998 setting up a network for the epidemiological surveillance and control of communicable diseases in the Community', OJ L 268/1, 3 October.

European Police Mission in Bosnia and Herzegovina (2006) 'Fighting Major and Organised Crime in Bosnia and Herzegovina: The State Investigation and Protection Agency', available at www.eupm.org/Clanci.asp?ID=79\&lang=eng (accessed 14 August 2006).

European Police Mission in Bosnia and Herzegovina (2006) 'Securing the borders of Bosnia and Herzegovia, the State Border Service (SBS)', available at www.eupm.org/Clanci.asp? ID=65\&lang=eng (accessed 14 August 2006).

European Union Factsheet (2005) 'EU Support for Iraq', available at http: //europa.eu/press_room/presspacks/us20050222/iraq.pdf (accessed 15 August 2006).

European Union Summaries of Legislation (2002) 'SCADPlus: The Common Foreign and Security Policy: Introduction', 13 February 2002, available at http: //europa.eu.int/scadplus/leg/en/lvb/r00001.htm (accessed 8 August 2006).

Europol (2006) Annual Report 2005 (The Hague: Europol).

Europol (2005) Annual Report 2004 (The Hague: Europol).

Europol (2004) Annual Report 2003 (The Hague: Europol).

Europol (2003) Annual Report 2002 (The Hague: Europol).

Europol (2002) Annual Report 2001 (The Hague: Europol).

Extraordinary Council Meeting (2001) (Justice, Home Affairs and Civil Protection), 'The fight against terrorism: Conclusions' 12019/01 (Presse 327-G).

'Joint Declaration by the British and French Governments on European Defence, at the Anglo-French Summit on November 25, 1999, in London', Internationale Politik, 1:2.

'Joint Declaration on European Defence (“St.-Malo Declaration”)', St Malo, 3-4 December 1998.

'Joint Statement by the Council and the Representatives of the Governments of the Member States meeting with the Council, the European Parliament and the Commission on "The European Consensus on Development", document no. $14820 / 05$.

Justice and Home Affairs Council (2006) 'First Report on the Hague Programme', available at http: //ec.europa.eu/justice_home/news/information_ dossiers/the_hague_2006/scoreboard (accessed 19 July 2006).

Justice and Home Affairs Council (1998) 'Action Plan of the Council and the Commission on how best to implement the provisions of the Treaty of 
Amsterdam on an area of freedom, security and justice', OJ C, 19/01, 23 January 1999.

Justice and Home Affairs Ministers (2004) 'Action against organised crime: The Dublin Declaration', Dublin, 22/23 January.

Luxembourg Presidency of the Council of the European Union (2005) 'Working Document Relating to Point 3 of the Agenda: Conceptual Framework on the ESDP Dimension to the Fight against Terrorism', 11 March 2005, available at www.eu2005.lu/en/actualites/documents_travail/2005/03/18defterr/index. html (accessed 15 July 2005).

Office for South East Europe (2006) 'How Much Money Is Being Given', available at www.seerecon.org/gen/howmuch.htm (accessed 14 August 2006).

Office of the High Representative and EU Special Representative (2003) 'Implementation of the Property Laws in Bosnia and Herzegovina Reached 90 per cent', Press Office, 12 November 2003, available at www.ohr.int/ohrdept/presso/pressr/default.asp? content_id=31164 (accessed 14 August 2006).

Permanent Representatives Council (2004) 'Adoption of Council Conclusions on prevention, preparedness and response to terrorist attacks', 15232/04, 25 November.

Pro-Eurojust (2002) Pro Eurojust: Report 2001 (Brussels: Pro Eurojust Secretariat).

Political and Security Committee (2004) 'Political and Security Committee Decision $\mathrm{BiH} / 4 / 2004$ of 19 October on the appointment of the head of the EU command element at Naples for the European Union military operation in Bosnia and Herzegovina', OJ L 357/38, 2 December.

Secretary General/High Representative (2006) 'Attachment 1: Improving our defence capabilities by increasing levels of research spending, finding opportunities for research collaboration, tackling capability gaps and collaborating as partners on training', S416/05, 14 December.

\section{Stability Pact documents}

Special Co-ordinator of the Stability Pact for South Eastern Europe (2004) 'Newsletter, 4 May 2004, Issue 21', available at www.stabilitypact.org/ newsletter/nl-21.pdf (accessed 14 August 2006).

Special Co-ordinator of the Stability Pact for South Eastern Europe (1999) 'Stability Pact for South Eastern Europe' (Cologne Document), Cologne, 10 June 1999, available at www.stabilitypact.org/constituent/990610-cologne.asp (accessed14 August 2006).

Stability Pact for South Eastern Europe (2005) 'Newsletter, 17-18 May 2005, Issue 22', available at www.stabilitypact.org/rt/RTSOFIANewsletter $\% 2022 \%$ 20-\%202\%20pages.pdf (accessed 14 August 2006). 